\title{
Intralingual Translation Has No Name in Turkey: Conceptual Crowdedness in Intralingual Translation
}

\section{Asl1 KALEM BAKKAL*}

This article aims to discuss the conceptual crowdedness in intralingual translation in Turkish with the hope to clear the way for it to be called by its own name, a step which may also hopefully still pave the way for intralingual translation to be seen as a type of 'proper' translation first by some scholars who currently oppose the idea, then by the agents of translation and eventually by the (Turkish) public. Departing from the view that one first needs its name to be recognized by its milieu before claiming a position in it, it is believed that refraining from using its name and replacing it with the names of translation strategies employed within it may be the major obstacle for intralingual translation to surmount if it is to take its 'proper' place in the field. Titles used for intralingual translation will be exemplified via publisher's notes, copyright pages, inner and back covers of different intralingual (re)translations of Hüseyin Rahmi Gürpınar's Gulyabani, with a special focus on two of them as they come from the same publisher: Can Yayınlar1. A theoretical discussion (indeed a metadiscussion as it is already on a discussion) will be held based on Karen Korning Zethsen and Aage Hill-Madsen's (2016) article, "Intralingual Translation and Its Place within Translation Studies: A Theoretical Discussion." Such metadiscussion will reflect on the views of various theorists and on some translational concepts in terms of their connotations for intralingual translation. Special emphasis will be on Roman Jakobson's tripartite classification and Gideon Toury's "assumed translation" concept.

Keywords: intralingual translation; name; position; properness; Gulyabani

\section{Introduction}

It is pleasing to see the increasing number of discussions and studies on intralingual translation in academic circles. Different views on this topic, regardless of whether they are for or against, help intralingual translation to get the attention it deserves. As it gets more attention in the academic world, it is believed that it may also become 'visible' in the sector as a translation activity per se. Considering the role intralingual translation plays today as a practice widely used not only in literary works but also in other disciplines where the jargon rules (e.g., medicine and law), academy-sector cooperation can be seen as indispensable to call intralingual

\footnotetext{
* Instructor and PhDc at Istanbul 29 Mayis University; part-time instructor at Izmir University of Economics. E-mail: aslibakkal71@gmail.com; ORCID ID: https://orcid.org/0000-0002-3952-1394.

(Received 26 August 2019; accepted 9 December 2019)
} 
translation by its name and thus to redefine its position. This article aims to argue for the need to call intralingual translation by its own name - as opposed to the names of translation strategies used within it — if it is to be accepted as 'proper' translation. ${ }^{1}$

Questioning the current place of intralingual translation in the academic circle and the possible reasons for its existing position will be based on Karen Korning Zethsen and Aage Hill-Madsen's (2016) article “Intralingual Translation and Its Place within Translation Studies: A Theoretical Discussion." The theoretical meta-discussion will be provided by presenting and evaluating views of different theorists, Roman Jakobson and Gideon Toury being the most prominent ones.

The object of study will be the intralingual (re)translations ${ }^{2}$ of Gulyabani (1938) by Hüseyin Rahmi Gürpınar. Two intralingual retranslations of the book will receive more focus as they are published by the same publisher (Can Yayınları) at the same time (January 2019), one presented as "the original text with explanations" and the other as the version "with contemporary Turkish." 3

Not calling intralingual translation by its own name can be considered as both the reason for and the consequence of the 'invisible' position intralingual translation holds today, especially when compared to interlingual translation. If it is to be regarded as the reason, raising and increasing awareness as to the presence of intralingual as a type of proper translation deserving to be called by its own specific name can be a good step forward. On the other hand, if the picture depicted in the above paragraph is to be considered as a consequence, it is now time to look back.

\section{Discussion within the Theoretical Framework Drawn by Zethsen and Hill-Madsen}

Considered as the father of intralingual translation by Susan Lotz $(2017,169)$, Roman Jakobson ([1959] 2004) includes intralingual translation within the field of translation in his

\footnotetext{
${ }^{1}$ It should be noted that the depicted situation is mainly based on Turkey. Although intralingual translation may be facing a similar situation in other countries, such a claim extends the scope of this paper.

${ }^{2}$ Given the numerous intralingual retranslations of Turkish classics, it becomes evident that intertextuality in retranslation discussed by Huanyao Zhang and Huijuan Ma (2018) is a topic which lends itself well also to intralingual translation studies. Intralingual (re)translations from the perspective of IR-abbreviation as used by the authors to refer to intertextuality in retranslation-may be discussed in another article.

${ }^{3}$ As there are two intralingual translations of Gulyabani published by Can Yayınları in 2019, "the original text with explanations" (açıklamalı orijinal metin) and the one "with contemporary Turkish" (günümüz Türkçesiyle) as the publisher differentiates, Can Yayınları Original will be used for the former whereas the latter will be referred to as Can Yayınları Contemporary from this point on in order to avoid confusion.
} 
tripartite categorization of translation, but defines only the 'interlingual' one as translation proper: "interpretation of verbal signs by means of some other language" (233). With this definition, as discussed below, interlingual translation can be said to claim the 'main' position, 'superior' to the other two, namely 'intralingual' and 'intersemiotic' translations, defined by Jakobson (233) as "interpretation of verbal signs by means of other signs of the same language" and as "interpretation of verbal signs by means of signs of nonverbal sign systems" respectively. ${ }^{4}$

This aspect of Jakobson's triadic division can be seen among the reasons for the invisible position of intralingual translation, for its being so 'improper' that it is almost refrained from articulating its name. As quoted by Hilla Karas (2016, 447), Theo Hermans (1996) argues that "the qualifier 'proper' suggests . . . that the other two are somehow not 'properly' translation." Within the same framework, Zethsen and Hill-Madsen (2016, 694-695) refer to Jacques Derrida (1985), who underlines the difference in approach to defining three types of translation: While 'intralingual' and 'intersemiotic' translations "are translated intralingually" by Jakobson as rewording and transmutation respectively, "the central word translation is simply repeated" to define interlingual translation. Thus, it is argued that interlingual translation is seen as "translation in the ordinary sense" while the other two are considered as "translation in the figurative sense."

The three postulates Toury puts forward for his concept of "assumed translation" have also been evaluated from the intralingual translation perspective. Zethsen and Hill-Madsen (2016) read Toury's transfer and relationship postulates "as Toury's own specification of the grounds for 'assuming,' i.e. for regarding a given text as a translation" (703). Claiming that Toury's (1995) definition is a "criterial" one in this regard, they also draw attention to the concept of "assumed translation." They mention the conception that "there is no pretense that the nature of translation is given or fixed in any way" (quoted in Zethsen and Hill-Madsen 2016) and argue that this translates into "translation [being] defined by the assumptions of any given target culture" (703).

The first of the three postulates by Toury (i.e., the source text postulate), which reads as "the obvious assumption that there is another text, in another culture/language, which has both

\footnotetext{
${ }^{4}$ Whether intersemiotic translation is seen as translation or not will not serve the discussion in this article as it does not share the same system with the other two types. The discussion in this article stems from the hierarchical inequality between two types of translation that share the same system — the verbal sign system.
} 
chronological and logical priority over it," is also evaluated by Zethsen and Hill-Madsen for its linguality aspect. Arguing that "linguality cannot be elevated to criterial status" whereas culture "has been shown to be intimately linked with communication barriers necessitating translation," the two scholars find "the conception of cultures as co-extensive with 'national' languages only much too simplistic" $(2016,704)$.

The issue of language will be further discussed in the following section as its denotations seem to be determinant for intralingual translation and its no-name position.

\section{3. 'Foreign' Language as a Criterion for the Definition of Translation}

What is a foreign language? Which language is foreign? For whom a language is foreign? When is a language foreign? Are there any differences between foreign and 'foreignized' languages? These are all questions that deserve a study on their own, necessitating also the knowledge of language philosophy. Having said that, it is important to mention in this article different and contradictory views on the definition of language as these may provide important clues for understanding the position of intralingual translation.

Brian Mossop (2016), who strongly argues against naming intralingual as 'translation,' bases his claims on his definition of "lingua," with very subjective and not clearly defined criteria:

A 'lingua' is, first, the unique phonological (or manual) and lexical-syntactic system which everyone acquires as an infant, or an additional such system learned later in life. ... A lingua $X$ (the source lingua) is different from another lingua $Y$ (the target lingua) if the lexicon, the syntax or the sounding/spelling/signing of $X$ are sufficiently different from those of Y.... Consequently, if the dialect being spoken on a television program is sufficiently different from that of most listeners, then the captions provided to assist them are interlingual, not intralingual. (5; bold emphasis mine)

By the same token, Mossop defines the translations of Turkish classics discussed by Özlem Berk Albachten ${ }^{5}$ (2014) — within the framework of Turkish language reform in 1928 after the foundation of the Republic of Turkey by Mustafa Kemal Atatürk — not as intralingual, but as interlingual. Based on "his proposed definition of lingua," he also calls "new versions

\footnotetext{
${ }^{5}$ For further information and discussion on intralingual translation in Turkish, see also Berk Albachten 2005, 2012, 2015; Birkan Baydan 2011; Kalem Bakkal 2019; Karadağ 2019.
} 
[that] contain major omissions and additions" not translation, but 'content editing' (Mossop 2016, 7).

Klaus Schubert (2005 quoted in Zethsen and Hill-Madsen 2016, 701) joins Mossop in his exclusion of intralingual from the concept of translation by this definition: "To translate means to render a text into a different language. Translation is by definition interlingual."

Mossop's and Schubert's points of view illustrate very clearly the close connection between the way language is defined and the position of intralingual translation. Discussing the merit of such a definition is beyond the aim and scope of this article. Nevertheless, it should be remembered that the language is a living entity which changes in time, as all living entities do, and this fact may make defining a 'lingua' as 'foreign,' which requires an 'interlingual' translation, not always an easy task. Can Ottoman Turkish, for example, which has turned into modern Turkish in time, be defined as 'foreign' just based on the criterion of 'intelligibility'? In today's Turkish culture, different groups of people can be said to have different degrees of 'understanding' Ottoman Turkish depending on their age, interest or education.

Benjamin Schmid (2008), a scholar who emphasizes this point and regards language within the context of culture, is also quoted in Zethsen and Hill-Madsen (2016). Schmid "points out that cultural borderlines are not restricted to those running between cultures encoded in the semantics of a 'national' language." He explains the nonuniformity in a given 'national' language via culture seen as a "conceptual system": "There are a lot of smaller cultures within a 'language community' that conceptualize aspects of the world differently and thus have to recur to processes of translation in order to guarantee successful communication among each other" (702).

Schmid underlines that "the fuzziness of languages as separate entities makes interlinguality a far from solid basis on which to build a demarcation criterion of translation." For Schmid, "boundaries between languages in many cases reflect socio-political conventions, and not any linguistic characteristics" (701). Schmid's point is supported by Peter H. Matthews (2005), quoted in Zethsen and Hill-Madsen (2016, 701), who claims that the artificial barrier created by politically determined conventions "defies the criterion of mutual intelligibility as the means of distinguishing languages from dialects." Ronald Wardaugh (1986), also quoted in Zethsen and Hill-Madsen (2016, 701-702), strengthens this view by exemplifying "the fact that two dialects on each side of a national border, recognized by convention as belonging to 
different languages, may well have more characteristics in common than two geographically distant dialects within the 'same' language."

As opposed to Mossop, Zethsen and Hill-Madsen $(2016,693)$ consider the 'language' component not as an obstacle for intralingual to be accepted as translation, but on the contrary, as the very reason for its inclusion in the concept of translation: "If interlingual translation consists in the transcending of a linguistic barrier, i.e. between two different language systems, INTRA ${ }^{6}$ must be defined as the crossing of a language-internal barrier."

Hill-Madsen $(2015,87)$ also stresses the existence and nature of barriers:

... translation transcends a semiotic barrier. . . In the case of interlingual translation, this barrier is easily recognized, but language-internal barriers exist, too, such as the one between mutually unintelligible dialects or the one between an expert and a layman's register ... . and it is the existence of such barriers, and the possibility of mediating across them, which makes the nature of intralingual translation at bottom no different from its interlingual sibling. ... .

Although these views can be considered as strong arguments against those that reject the inclusion of intralingual into the concept of translation, there is another factor that could account for its exclusion. That factor is 'equivalence.'

\section{Equivalence: A Hindrance for Intralingual Translation?}

Equivalence, taken as a criterion to distinguish between 'translation' and 'nontranslation' (Zethsen and Hill-Madsen 2016, 697-698) mostly in the framework of interlingual translation, can be thought of as having its reflections also on the positioning of intralingual translation. This 'false' criterion is a concept that has been debated on and exposed to many criticisms in translation studies.

Mossop (2016), who refuses the inclusion of intralingual translation into translation studies, is among the scholars who question the 'issue of equivalence.' He suggests using "equivalencing" as criterion: "producing a target-language wording which they [translators] think means more or less the same as the corresponding passage in the source text." (1)

One of the scholars mentioned by Zethsen and Hill-Madsen $(2016,698)$ within this framework is Werner Koller (1995), who bases his view on the "double linkage" of

\footnotetext{
${ }^{6}$ In the article in question, the authors refer to intralingual translation as INTRA.
} 
transLogos 2019 Vol 2 Issue 2

Kalem Bakkal, Asl1, pp. 48-69

Intralingual Translation Has No Name in

A Translation Studies Journal

Turkey: Conceptual Crowdedness in

Intralingual Translation

(C) Diye Global Communications diye.com.tr|diye@diye.com.tr

translations - the link of the target text (TT) with the source text (ST) and the link between the TT and the target audience. The two scholars summarize Koller's point as follows: "Equivalence in the form of faithfulness to the source text is in many cases inadequate if a TT is to succeed in providing its readers with proper access to the content of the ST" (698). Zethsen and Hill-Madsen (2016) also refer to Maria Tymoczko's (1999) emphasis on the partiality of translations - that "[translations] can only 'stand for' part of the original text"; Derrida's ([1972] 1981) belief that "the signified is inseparable from the signifier" (i.e., selected "TL signifiants signify TL meanings which do not per se 'refer back to' ST meanings"); Andrew Chesterman and Rosemary Arrojo's (2000) term of non-essentialism (i.e., “meanings are always context-bound and that there are no stable, objective meanings that let themselves be 'carried across' from ST to TT”); George Steiner's (1975/2012) hermeneutics, which understands translation as "TT meanings making sense of ST meanings through replacement"; Mary Snell-Hornby's ([1988] 1995) inference that "translation becomes logically impossible, at least if semantic identity is stipulated as criterial to translation" (quoted in 698-699). What Zethsen and Hill-Madsen conclude in this regard is "the impossibility of equivalence in the sense of "complete semantic identity"' (699).

While equivalence is regarded as 'impossible' by "most modern translation scholars" (Zethsen and Hill-Madsen 2016, 699), it looks like this concept is in the very heart of the 'institutional' arena of translation (cf. Zethsen and Hill-Madsen 2016, 694). This arena comprises dictionaries, translation activities, translator training institutes, translators, publishers, editors and readers, to name some (cf. Hermans 1995 in Zethsen and Hill-Madsen 2016, 694). As also quoted by Zethsen and Hill-Madsen (2016, 694), in this institutional milieu, "what external stakeholders expect" is "equivalence in translation," "a relation of sameness between what they [consumers of translation] read and the ST" (Hermans 1995). The article also refers to Anthony Pym (1995), who defines translator as "an equivalence producer" and who also notes that the expectation of equivalence is what "enables translations-and translators - to work" (quoted in Zethsen and Hill-Madsen 2016, 694). This expectation could be among the reasons for intralingual translation not to be called by its own name by its producers and receivers (i.e., 'the folk.') 


\section{Reflections on the Perception of Translation by the 'Folk'}

Zethsen and Hill-Madsen $(2016,696)$ refer to M. A. K. Halliday and Christian M. I. M. Matthiessen (1999) as they relate "the divergence between scientific taxonomies and so-called folk ones belonging to the "same' field of experience" to "classificatory criteria": as one moves from "folk taxonomies to scientific ones," "overt criteria accessible to the naked eye" become "covert" and "available only through the application of scientific techniques." Looking at "overt criteria' for the Turkish folk's definition of translation, it can be argued that the general view echoes the prerequisite of "some other language" put forward by the definition of interlingual translation (Jakobson [1959] 2004, 233) and "the current dominant/canonized understanding of translation which is in line with the norm of "complete fidelity to source text"", (Paker 2014, $42)^{8}$; in other words, a source text in a 'foreign' language and an end product that is 'the same' as the original are considered to be necessary for the label of 'translation.' What is 'foreign' and 'the same,' however, become 'covert'-and complex - when discussed in scientific terms.

As emphasized by Zethsen and Hill-Madsen (2016, 697), Richard Robinson (2011) approaches the issue from another perspective and "maintains that so-called nominal definitions (definitions of the names we give to things) ... are valid simply as a matter of convention." As a matter of such a convention, the term "translation" is defined in one of the most comprehensive Turkish dictionaries as " 1 . Transferring from one language to another, translating, interpreting; 2. A text or a book translated from one language to another, interpretation." 9

While the issue of language discussed earlier seems to be one of the factors determining the translational framework in the minds of the folk, Clare Vassallo $(2015,167)$ argues that "Jakobson's inspired choice of the word 'proper"" has determined "the parameters of what an acceptable translation is." Although the audience of a target text - and probably also many agents of translation - may not be knowledgeable about Jakobson and his use of 'proper,' Vassallo claims that

the term "proper," with its associations of "correctness," "suitability," "conformity to social norms," and "truthfulness," seems to lay down the contractual terms that a

\footnotetext{
7 ،“günümüzde hâkim olan/saygın sayılan kaynak metne tam olarak bağlılık’ normuna uygun çeviri anlayışı”

${ }^{8}$ All translations are mine unless otherwise stated.

${ }^{9}$ Türkçe Sözlük (Turkish dictionary), 2005, s.v. "çeviri”; “1. Bir dilden başka bir dile aktarma, çevirme, tercüme;

2. Bir dilden başka bir dile çevrilmiş yazı veya kitap, tercüme."
} 
translator is expected to deliver of a text that is defined as a translation and that a reader of a translated text should reasonably expect to have delivered. (167)

The possibility of a translator as a figure in the institutional arena of translation having this notion of translation in her/his mind can account for the limited definition of translation in public in general.

It is worth revisiting Toury's notion of "assumed translation" at this point. As stated earlier, Zethsen and Hill-Madsen (2016) point out that with this notion "translation is defined by the assumptions of any given target culture," and warn against a reverse case:

Toury's stance invites folk notions to interfere with a scholarly definition, and there is no guarantee that such folk notions (European or non-European) may not be more exclusive than a scholarly approach, contrary to the intentions behind the relativistic stance. (703)

Although one can argue against the authors stating that Toury's concept aims to determine the object of study of translation studies rather than to give a definition of translation, this does not alter the fact that the reverse case mentioned in the article is just exemplified by the situation of intralingual translation in Turkey, where agents of translation and the target readers generally tend not to call the process and the product 'intralingual translation,' ${ }^{10}$ though there are also a few examples of the contrary. Being one of the prominent Turkish scholars focusing on intralingual translation as the object of study, Esra Birkan Baydan (2011) mentions Tülay Gençtürk Demircioğlu's naming her translation of Fatma Aliye Hanım’s Enin (1910) as “intralingual translation” and the presentation of Güler Güven's translation of Sâmipaşazâde Sezâyi's Kediler (1891) published in Metis Çeviri (3) (1988) as "An Example of Intralingual Translation." Another interesting example at this point is indicated by Ayşe Banu Karadağ (2017), who examines two versions of Filibeli Ahmed Hilmi's Â'mâk-ı Hâyal (1910), widely accepted as the first philosophical novel of the Turkish literature, published by İnsan Kitap in 2016. Karadağ finds out that although the procedures employed in the two are not quite different, one of them is presented as 'transcription' ${ }^{11}$ and the other as 'translation' with the name Abdurrahman Badeci stated as 'translator.' However, while the term 'translation' is on

\footnotetext{
${ }^{10}$ For a conversation on 'intralingual translation' covering how it has been practiced and addressed in the Turkish literary system, see Canseven 2017.

${ }^{11}$ For a study on how transcribed works have been labeled in the Turkish literary system, see Durmaz Hut 2019.
} 
the front cover and the term "prepared for publication" on the title page, 'intralingual' does not appear on the book.

A similar abstinence from use of the term 'intralingual translation' is also exemplified by Baydere and Karadağ $(2019 a ; 2019 b)$ as part of their research on translational adventure of Çalıkuşu, ${ }^{12}$ a Turkish classic by Reşat Nuri Güntekin. As a matter of fact, Nihan Abir (2012), a Turkish literature researcher conducting an elaborated thesis study on Çalıkuşu (1922) written in Ottoman Turkish and its 'rewritten' version (1939) in Latin alphabet by Güntekin himself, makes no mention of the term 'translation,' let alone 'intralingual translation,' to describe the process whereby Çalıkuşu was "presented to readers through modification" (vi). Baydere and Karadağ, on the other hand, take such "rewriting" as "intralingual translation" and "intralingual self-translation" (2019b, 316), thereby illustrating an example of 'no name' for '(intralingual) translation' in Turkology research.

With all this considered, it may be argued that calling intralingual translation by its own name instead of the translation strategies employed within it - many of them also used within interlingual translation - can be a step towards overcoming the constraints of a limited conception of translation.

\section{Translation Strategies Used in Intralingual Translation: Intralingual (Re)Translations of Hüseyin Rahmi Gürpınar's Gulyabani}

In line with the current trend in Turkey, various intralingual translations and retranslations of Hüseyin Rahmi Gürpınar's Gulyabani have taken their place on the shelves of almost all bookstores. ${ }^{13}$ Being the work of a writer known as one of the most important representatives of realism and naturalism of his time, Gulyabani is considered among the most significant classic novels of Turkish literature. Gulyabani, with the characteristics of its intralingual (re)translations, can be seen as a representative of the situation of intralingual translation in Turkey.

\footnotetext{
${ }^{12}$ A comprehensive PhD dissertation (2019-) titled Çalıkuşu'nun Çeviri Serüveni [Translational adventure of Çalıkuşu] focusing on Çalıkuşu's intergenre, intralingual, and interlingual translations is currently being prepared by Muhammed Baydere under the supervision of Ayşe Banu Karadağ at Yıldız Technical University (Turkey).

${ }^{13}$ Since the language reform in 1928, many Turkish classics have been intralingually translated, some of them by their own authors. For a study focusing on an intralingual case where the author acted as intralingual selftranslator' in the Turkish literary system, see Baydere and Karadağ 2019b. For a study focusing on an English example of intralingual self-translation, see Canlı 2018a, 2018b, 2019.
} 


\subsection{Presentation of Gulyabani to Target Readers}

As noted earlier, in the reverse situation of what "assumed translation" foresees (i.e., when the folk's definition of translation is much narrower than the academic milieu's), the producers of translation may feel the need to 'justify' their action:

In their prefatory statements, the translators, editors, and publishers claim the need of a new and simplified text for new generations because of the dated language of the previous versions, expressing at the same time their concern about preserving the author's style, syntax and structure. (Berk Albachten 2014, 579)

The way Gürpınar's Gulyabani is presented to target readers just exemplifies what Berk Albachten - one of the most prominent scholars writing about intralingual translation in Turkey-emphasizes the reverse situation in Turkey:

... we present Gulyabani in a simplified form by protecting its original style as much as possible. ${ }^{14}$ (2015b; İthaki back cover)

We present this unique masterpiece of our literature after a comparative work carried out on its first publications, with explanatory footnotes and without interfering with its original language. ${ }^{15}$ (2019; Can Yayınları Original back cover)

We present this unique masterpiece of our literature as adapted to contemporary Turkish, with the least interference in its original language. ${ }^{16}$ (2019; Can Yayınlar1 Contemporary back cover)

As these presentations of the book illustrate, intralingual translation, let alone being called with its own name, seems to be considered as something requiring 'camouflage,' as if what is done were a betrayal of the source text. ${ }^{17}$ All the examples serve to further illustrate what Berk Albachten (2014) underlines, namely why intralingually translated versions of Turkish classics are claimed not to be "translated versions but reproductions of originals":

Hence, they are not presented to readers as intralingual translations, for the notion of "translation" appears to these editors, translators and publishers as something that distorts the original. They believe that the replacement of words by synonyms and the

\footnotetext{
14 “. . . Gulyabani’yi, eserin orijinal üslubunun elden geldiğince korunduğu sadeleştirişmiş haliyle sunuyoruz."

15 "Edebiyatımızın bu eşsiz başyapıtını ilk baskıları üzerinde yapılan karşılaştırmalı çalışma ve açıklayıcı dipnotlarla, özgün diline müdahale etmeden sunuyoruz."

16 "Edebiyatımızın bu eşsiz başyapıtını orijinal diline en az müdahaleyle günümüz Türkçesine uyarlanmış olarak sunuyoruz."

${ }^{17}$ For a study discussing a translator's attempt to call his translation 'not a translation' and himself 'not a translator' in the context of such translation due to its deviation from the source text and not reflecting all what was intended by the source text author, see Baydere 2018 .
} 
use of various paratexts do not change the author's style, syntax or structure, and that they can produce the same text and the same meaning. . . . (581)

The situation of intralingual translation in Turkey can be further explained by mentioning Karas (2016, 453), who, while discussing états de langue, points out that in a context where the language - Ottoman Turkish in this case- "is considered an older variety of the modern language ... reservations may be raised concerning the term "translation."

\subsection{Presentation of the Translator in Gulyabani}

As a natural result of this understanding, the person carrying out the task of intralingual translation is almost never called a translator. Instead, her/his title is given after the strategy followed in the process, a case also exemplified by intralingual translations of Gulyabani: “editor" (editör; 2019; Can Yayınları Original), "adapted to contemporary Turkish by"18 (günümüz Türkçesine uyarlayan; 2019; Can Yayınları Contemporary), "simplified from Ottoman Turkish by” (Osmanlicadan sadeleştiren; 2016; Kırmızı Kedi Yayınevi), “contemporary Turkish by" and "prepared for publishing by"19 (respectively günümüz Türkçesi and yayına hazırlayan; 2015a; Everest Yayınları), "prepared with contemporary Turkish by" (günümüz Türkçesiyle hazırlayan; 2018; Bilgi Yayınevi), "transcribed and simplified by" (çevrimyazı ve sadeleştirme; 2017; İnkılâp Kitabevi).

Berk Albachten $(2014,579)$ also points out:

Intralingual translations of Turkish literary texts are generally not regarded as "translations" and ... usually function as original texts since the original versions are no longer on the market. This has resulted in their exclusion from research within translation studies. A limited number of studies by translation scholars discuss the strategies followed in these intralingual translations.

\subsection{Intralingual Translation Strategies}

Some common intralingual translation strategies include, but are not limited to, 'simplifying,' 'summarizing,' 'arranging,' 'preparing for publishing,' 'editing,' 'transferring by summarizing,' 'adapting,' 'abridging,' 'Turkifying,' in the case of Turkish being the target

\footnotetext{
${ }^{18}$ It should be noted that both the "editor" in Can Yayınları Original and the person referred to in the mark "adapted to contemporary Turkish by" in Can Yayınları Contemporary are the same person.

${ }^{19}$ Different people are responsible of these two tasks.
} 
language, most of which are also reported to be used in naming intralingual translations in Turkish context by Berk Albachten $(2005 ; 2015)$.

All of the above are the strategies used in intralingual translation. Just like translators use different translation strategies while doing interlingual translation, intralingual translation also provides translators with various strategies. Furthermore, strategies used in both types of translation are most of the time alike, such as arranging the syntax, opting for a more modern word instead of an old one, adapting the cultural components accordingly, even summarizing, explaining, adding and omitting, to name a few. ${ }^{20}$ This view is also put forward by Zethsen $(2009,808)$ as "[a]1l strategies found in the intralingual versions are well-known within interlingual translation, but not necessarily with the aim of simplification and not to the extent seen in intralingual translation."

That the strategies used in intralingual translation are similar to the ones used in interlingual translation is a fact also expressed by Mossop:

Intralingual rewriters are ... writing for a new audience which differs from the original audience by some feature other than the languages they know, such as expertise or age.... They ... will be adding and subtracting information to make the text understandable to the new audience. ... Translators, by contrast, do not typically make such large-scale adaptations to the readership.

Based on this claim, one wonders whether the new audience of interlingual translation is different from the source audience solely in terms of the language they know. Could not there be - are not there - any differences between the two groups of audience also in terms of age, gender or expertise? Are not there any instances in which 'interlingual translators' 'also' need to adjust their 'translation' according to the 'new audience'? Apparently, there are, as Mossop $(2016,9)$ states:

That said, translators do indeed now and then add explanations or clarify by adjusting the level of language. ... There are many more translational activities which vary some aspect of the source rather than preserve it: examples would be reparagraphing; improving the structure of poorly written source texts; reworking the typography and layout of the text; correcting mathematical errors in the source text; omitting passages of the source text from the translation.... (emphasis mine)

\footnotetext{
${ }^{20}$ A detailed study on the similarities between intralingual and interlingual translation strategies can provide important clues for redefining the status of intralingual translation.
} 
Again, Mossop's evaluation is based on a concept, the definition of which is pretty vague. How often is 'now and then'? How often is 'too much' to label a translation as 'nontranslation'? Why are these strategies called 'translation strategies' when used in interlingual translation, but put forward as reasons to label intralingual translation as 'non-translation' when used within it?

Departing from Mossop's observations, one could deduce what Zethsen claims: "[T]his suggests that generally the difference in strategies between intralingual and interlingual translation is a question of degree and motivation rather than kind" $(2009,809)$.

Interestingly enough, Mossop reaches a totally different understanding with regard to the position and naming of intralingual translation: "I suggest that a translator's activity when working interlingually is so different ... from that of same-language producers of derived texts that the latter should not be seen as a kind of translation" (2016, 1-2).

It is worth repeating that although "the omissions, additions, restructuring, etc. seen in intralingual translation are more extreme than is generally the case in translation proper" (Zethsen 2009, 795-812), this does not change the fact that what differentiates intralingual translation from the interlingual in terms of strategies is "a question of degree and motivation rather than kind" (809). The degree and type of the strategies used are determined by various factors, just like in interlingual translation.

As to the 'degree' of translation, it is worth mentioning Saliha Paker's $(2014,40)$ reference to "violence of translation" present in "its own aim and in the constitution of its activity" 21 and her mention of Lawrence Venuti's (2010) statement that "translation is the forcible replacement of the linguistic and cultural difference of the foreign text with a text that will be intelligible to the target-language reader."

Intralingual (re)translations of a book use different combinations of translation strategies, in different degrees. They may drive one strategy — or a combination of two strategies - forward and introduce themselves with the name of that strategy. That a publisher launches simultaneously more than one intralingual (re)translation of the same book with different 'strategy names' is a very common practice in Turkey nowadays, as mentioned earlier,

\footnotetext{
21 “Çevirinin şiddeti kendi amacında ve etkinliğinin bünyesinde mevcuttur. . .” (Paker 2014, 40)
} 
transLogos 2019 Vol 2 Issue 2

Kalem Bakkal, Asl1, pp. 48-69

Intralingual Translation Has No Name in

trans Dogos

A Translation Studies Journal

Turkey: Conceptual Crowdedness in

Intralingual Translation

(C) Diye Global Communications diye.com.tr $\mid$ diye@diye.com.tr

especially in the framework of intralingual (re)translations of Turkish classics. ${ }^{22}$ Below are two examples of intralingual retranslations from the 21 st century Turkish literature: two versions of Gulyabani by Can Yayınları, with different strategies. ${ }^{23}$

\section{Gulyabani Original and Gulyabani Contemporary by Can Yayınları}

Can Yayınları explains the strategies used in each of the intralingual retranslationsthough they do not call them this way-in the "Publisher's Note" sections of the books. ${ }^{24}$

Both notes are composed of two paragraphs, but their order differs. Whereas the "Publisher's Note" of the Contemporary (Gürpınar 2019b) begins with the paragraph that includes information on the source text, reference to later publications and how they have been used, this paragraph appears as the second paragraph in the Original (Gürpınar 2019a).

While preparing this book we took as the basis the 1938 publication, which was published while the author was alive, prepared with Latin letters and simplified language. We compared that publication with the first publication of the book. We did not note the simplifications, we noted the changes regarding the meaning and the sentence structure in footnotes. When necessary, we also referred to later publications. (2019a, 9; Original) ${ }^{25}$

While preparing this book we took as the basis the 1938 publication, which was published while the author was alive, prepared with Latin letters and simplified language. We compared that publication with the first publication of the book. We noted the changes regarding the meaning and the sentence structure in footnotes. When necessary, we also referred to later publications. (2019b, 9; Contemporary $)^{26}$

While preparing this book, we did not interfere in the author's language, style, word choice; we only adapted his spelling to contemporary rules. We prepared a dictionary at the end of the book for Arabic, Farsi words that are no longer used much. We tried to write the foreign words also in their original form. We tried to give the meanings of some Turkish origin words, folk sayings that are not frequently used today and some

\footnotetext{
${ }^{22}$ The fact that there are many different intralingual translations of the same book by different publishers reminds of the ideological role translation — intralingual in this case - plays in a target system. For a study focusing on 'rewriting' and 'patronage' in intralingual translation, see Öztürk Baydere 2019.

${ }^{23}$ For a study addressing the use of a variety of "(micro) strategies applied in [intralingual translations]" with two examples from the 19th century Ottoman literature, see Berk Albachten 2019.

${ }^{24}$ Parts written in normal fonts are exactly the same in both texts. Italic parts refer to differences between the two. Bold and italic parts are to emphasize the sections to be discussed in the article.

25 "Elinizdeki kitabı yayına hazırlarken yazar hayattayken yapılan, dili sadeleştirilerek hazırlanmış Latin harfli 1938 baskısını esas aldık. Bu baskıyı kitabın ilk baskısıyla karşılaştırdık. Sadeleştirmeleri not düşmedik, anlama ve cümle düzenine dair değişiklikleri dipnotlarda belirttik. Gerek gördükçe daha sonra yapılan baskılara da başvurduk."

26 "Elinizdeki kitabı yayına hazırlarken yazar hayattayken yapılan, dili sadeleştirilerek hazırlanmış Latin harfli 1938 baskısını esas aldık. Bu baskıyı kitabın ilk baskısıyla karşılaştırdık. Anlama ve cümle düzenine dair değişiklikleri dipnotlarda belirttik. Gerek gördükçe daha sonra yapılan baskılara da başvurduk."
} 
necessary explanatory information on the daily life and the period in footnotes. (2019a, 9; Original) ${ }^{27}$

While adapting the book to contemporary Turkish, we tried, with least interference in the author's language, to find the most appropriate equivalents for Arabic, Farsi words and compounds that have been almost completely removed from Turkish dictionaries; even it was the exact equivalent of the word in the book, we did not use new words that could harm the text harmony. We did not interfere in the words that are still in use, the words the meaning of which could be figured out from the context; we prepared a dictionary for these at the end of the book. Also, we tried to give the meanings of some Turkish origin words, folk sayings in the dictionary. (2019b, 9; Contemporary) ${ }^{28}$

The concern of 'protecting the author's language' is clearly seen in both texts. The statements of "least interference" and "we did not interfere" may be considered as referring to the sensitivity of 'not betraying the source text.' It should be noted at this point that these two works are in fact intralingual retranslations as their 'main' source text is also a translation. In this respect, what they argue to be loyal to is not the original Gulyabani written by Hüseyin Rahmi Gürpınar, but a transcribed and intralingually translated version of it.

It can also be observed that the main 'interference' is at lexical level in both books, according to their publisher's notes. The basic difference in this sense seems to be in the placement of Turkish equivalents. In the Original, Turkish equivalents or explanations are mostly given in footnotes and the dictionary is mostly used for Arabic and Farsi words' definitions whereas in the Contemporary, Arabic and Farsi words in the text are replaced by their Turkish equivalents and the dictionary at the end is reserved to the definitions of cultural concepts, hence much shorter than the other dictionary.

At this point, Paker's article (2004) can shed more light on the issue. In her study where she reflects on Andreas Huyssen's views, Paker underlines the 'permeability' between yesterday and today by citing Huyssen's $(2003,1)$ observation: “The boundary between past

\footnotetext{
27 “Bu kitabı hazırlarken yazarın diline, üslubuna, kelime tercihlerine müdahale etmedik; sadece imlasını günümüz kurallarına uyarladık. Artık pek kullanılmayan Arapça, Farsça kelimeler için kitabın sonunda bir sözlük hazırladık. Yabancı kelimeleri de özgün şekilleriyle yazmaya çalıştık. Bugün sık kullanılmayan Türkçe kökenli bazı kelimelerin, halk deyişlerinin anlamlarını, gündelik hayata ve döneme dair gerekli bazı açıklayıcı bilgileri de dipnotlarda vermeye çalıştık."

28 "Kitabı günümüz Türkçesine uyarlarken yazarın diline en az müdahaleyle artık Türkçe sözlüklerden neredeyse tamamen çıkmış Arapça, Farsça kelimeler ve terkipler için en uygun karşılıkları bulmaya çalıştık; kitaptaki kelimenin tam karşılığı olsa bile metnin ahengini bozacak türdeki yeni kelimeleri metinde kullanmadık. Az da olsa hala kullanımda olan, bağlamdan anlamı çıkarılabilen kelimelere müdahale etmedik, bunlar için kitabın sonuna bir sözlük hazırladık. Ayrıca bugün sık kullanılmayan Türkçe kökenli bazı kelimelerin, halk deyişlerinin anlamlarını da sözlükte vermeye çalıştık."
} 
and present used to be stronger and more stable than it appears to be today." In the study under question, the permeability between past and present becomes obvious at lexical level. Many words 'from the past' are still widely used in contemporary Turkish, as exemplified by the words used in the "Publisher's Note" itself of the Contemporary version such as müdahale, ahenk, terkip ${ }^{29}$ just to name a few. Likewise, in the Original version's "Publisher's Note," many words 'from the present' like sözlük, yazar, bilgi ${ }^{30}$ are used.

Karas $(2016,460)$ points to Douglas Robinson's (1998) statement which may help to explain this situation: "Since the older état de langue is sometimes not considered as completely 'other' and unintelligible, both source and target language may be used in the target text, which turns out 'detemporalized." Following this, it can be said that in the case of Gulyabani, the 'detemporalized' language reveals itself even in the peritexts of both versions.

Can Yayınları refers to each of these intralingually translated versions of Gulyabani as "Hüseyin Rahmi Gürpınar's other book by Can Yayınları" in their inner page. It is true. Just like every interlingual (re)translation of a book is presented as an 'other' book, every intralingually (re)translated book is also an 'other' book. However, in the case of interlingual translation, one never knows what translation strategies the 'translator' has used in her/his translating activity whereas in the case of intralingual translation, one almost never hears of a 'translator' but knows in a very detailed way what translation strategy has been used as well as why, how and to what 'degree.' In Turkey, where even 'interlingual translators' do not see their names on the book covers very often, discussions and studies on intralingual translation may not only carry 'INTRA' to the position it 'deserves' but also help to broaden the boundaries of the concept of translation and hence empower the role of all translation agents.

\section{Conclusion}

This paper has set out with the purpose of raising awareness about the position of intralingual translation in Turkey. For this purpose, an overview of several parallel or contradictory, for or against views, theories and concepts of translation studies have been presented and tried to be associated with the subject of the study. Two intralingual translations of Hüseyin Rahmi Gürpınar's Gulyabani by Can Yayınları have been analyzed within this

\footnotetext{
29 'Old Turkish equivalents' for 'intervention,' 'harmony,' 'combination' respectively.

${ }^{30}$ Modern Turkish equivalents for 'dictionary,' 'author,' 'information' respectively.
} 
framework as a true example of the case in Turkey. By laying this theoretical groundwork, it has been aimed to present an overview - although not exhaustive - of the discussions on intralingual translation, to mirror the increasing number of reflections on the issue and to generate questions in the minds of people who have a say in the field.

Do translation producers refrain from naming what they do as intralingual translation because of the receivers' limited definition of translation? Or does the folk call intralingualthe target reader may not even have heard such a term, and this deserves a separate study - not a translation because of the translation producers who have been trained with a relatively limited notion of translation? Does the notion of equivalence have an effect on the current noname position of 'INTRA' in Turkey and, if it does, to what extent? What can be done to change the position of 'INTRA' in Turkey?

It is my strong belief that the more discussions and studies on 'INTRA' are held by academic circles, the more questions can be asked, the more of them can be answered, the newer insights may be brought into translation research, particularly within the context of Turkey intensely experiencing intralingual translation as a result of Turkish language reform. This, on the other hand, may be argued to call for an approach taking its source from where such translational practices take place, which may establish a sounder ground for research abstaining from the constraints of the limited conception of translation.

The faster we, scholars, become aware of the need to make 'INTRA' and its agents 'visible,' the smaller the gap between the academy and the agents of translation in terms of the definitions and usage of terms may get. This, in turn, may contribute to a wider acknowledgment of the broad scope of the concept of translation by all stakeholders of translation and addressing (specific) translational phenomena within their own reality. 


\section{References}

Abir, Nihan. 2012. "Çalıkuşu'nun Hikâyesi." [The story of Çalıkuşu.] Master's thesis, Mimar Sinan Fine Arts University.

Baydere, Muhammed. 2018. "A New (Mis)Conception in the Face of the (Un)Translatable: 'Terscüme." transLogos Translation Studies Journal 1 (1): 92-120. doi: 10.29228/transLogos.1/1.10.

—. 2019. "Çalıkuşu'nun Çeviri Serüveni.” [The translational adventure of Çalıkuşu.] Unpublished manuscript, last modified July 3. Microsoft Word file.

Baydere, Muhammed, and Ayşe Banu Karadağ. 2019a. "Çalıkuşu'nun Diliçi Çeviri Serüveni Üzerine Betimleyici Bir Çalışma." [A descriptive study on the intralingual translation adventure of Çalıkuşu.] Paper presented at the 2nd International Rumeli [Language, Literature and Translation] Symposium, Kirklareli, April 12-13.

2019b. "Çalıkuşu'nun Öz-Çeviri Serüveni Üzerine Betimleyici Bir Çalışma." [A descriptive study on the self-translation adventure of Çalıkuşu.] In "2nd International Rumeli Symposium [Language, Literature, Translation]," edited by Yakup Y1lmaz and Fatih Başpınar. Special Issue, RumeliDE Journal of Language and Literature Studies, no. 5, 314-333. doi:10.29000/rumelide.606165.

Berk Albachten, Özlem. 2005. "Diliçi Çeviriler ve Mai ve Siyah." [Intralingual translations and Mai ve Siyah.] Dilbilim 14:139-149. https://dergipark.org.tr/en/pub/iudilbilim/issue/1083/12247.

. 2012. 'Intralingual Translation as 'Modernization' of the Language: The Turkish Case.” Perspectives 21 (2): 257-271. doi:10.1080/0907676X.2012.702395.

2014. "Intralingual Translation: Discussions within Translation Studies and the Case of Turkey." In A Companion to Translation Studies, edited by Sandra Bermann and Catherine Porter, 573-585. West Sussex: Wiley Blackwell.

2015. "The Turkish Language Reform and Intralingual Translation." In Tradition, Tension and Translation in Turkey, edited by Şehnaz Tahir Gürçağlar, Saliha Paker, and John Milton, 165-180. Amsterdam: John Benjamins.

. 2019. "Challenging the Boundaries of Translation and Filling the Gaps in Translation History: Two Cases of Intralingual Translation from the 19th-Century Ottoman Literary Scene." In Moving Boundaries in Translation Studies, edited by Helle V. Dam, Matilde Nisbeth Brøgger, and Karen Korning Zethsen, 185-199. London: Routledge.

Birkan Baydan, Esra. 2011. "Editing as Rewriting." Istanbul University Journal of Translation Studies 2 (3): 53-78. https://dergipark.org.tr/en/pub/iuceviri/issue/1231/14424. 
transLogos 2019 Vol 2 Issue 2

Kalem Bakkal, Asl1, pp. 48-69

Intralingual Translation Has No Name in

A Translation Studies Journal

Turkey: Conceptual Crowdedness in

Intralingual Translation

(C) Diye Global Communications diye.com.tr|diye@diye.com.tr

Canlı, Gülsüm. 2018a. "Kavram Tanımlarının Ötesinde Bir Çeviri Eylemi: William Faulkner'ın Sanctuary Adlı Romanının Türk Erek Dizgesindeki Serüveni." [A translational act beyond definitions of concepts: The adventure of William Faulkner's Sanctuary in the Turkish target system.] In Çeviribilimde Güncel Tartışmalardan Kavramsal Sorgulamalara [From recent discussions to conceptual reflections in Translation Studies], edited by Seda Taş, 285-314. Istanbul: Hiperyayın.

. 2018b. "Relocating Self-Translation from the Interlingual to Intralingual: Faulkner as a Self-Translauthor." transLogos Translation Studies Journal 1 (1): 41-63. doi:10.29228/transLogos.1/1.8.

. 2019. 'William Faulkner'ın Sanctuary Adlı Romanının Kaynak ve Erek Dizgedeki Çeviri Serüveni: Diliçi Çeviri, Öz-Çeviri, Yeniden Çeviri ve Dolaylı Çeviri Kavramları Işı̆̆ında Bir İnceleme.” [The translational adventure of William Faulkner's Sanctuary in source and target systems: An analysis in the light of intralingual translation, selftranslation, retranslation and indirect translation.] $\mathrm{PhD}$ diss., Y1ld1z Technical University.

Canseven, Cansu. 2017. “Konuşmalar: Diliçi Çeviri.” [Conversations: Intralingual translation.] T24. April 13. https://t24.com.tr/k24/yazi/konusmalar-dilici-ceviri1,1152.

Durmaz Hut, Aytül. 2019. “Çevirinin Yansımaları Olarak 'Çeviriyazıların' Farklı Adlandırılışları Üzerine Bir Çalışma." [A study on different classification of 'transcriptions' as reflections of translation.] In Çeviribilimde Araştırmalar [Research in Translation Studies], edited by Seda Taş, 177-196. Istanbul: Hiperyayın.

Gürpınar, Hüseyin Rahmi. 1938. Gulyabani. Istanbul: Hilmi.

2015a. Gulyabani. Istanbul: Everest.

- 2015b. Gulyabani. Istanbul: İthaki.

. 2016. Gulyabani. Istanbul: Kırmız1 Kedi.

—. 2017. Gulyabani. Istanbul: İnkılâp.

-2018. Gulyabani. 2nd ed. Istanbul: Bilgi.

_. 2019a. Gulyabani Garaib Faturası Külliyatı Birinci Hikâye. Istanbul: Can.

—.2019b. Gulyabani Günümüz Türkçesiyle. Istanbul: Can.

Hill-Madsen, Aage. 2015. "Lexical Strategies in Intralingual Translation between Registers." Hermes: Journal of Language and Communication in Business 27 (54): 85-105. doi:10.7146/hjlcb.v27i54.22949. 
transLogos 2019 Vol 2 Issue 2

Kalem Bakkal, Asl1, pp. 48-69

Intralingual Translation Has No Name in

trans Dogos

A Translation Studies Journal

Turkey: Conceptual Crowdedness in

Intralingual Translation

(C) Diye Global Communications diye.com.tr|diye@diye.com.tr

Jakobson, Roman. (1959) 2004. "On Linguistic Aspects of Translation.” In The Translation Studies Reader, edited by Lawrence Venuti, 113-118. London: Routledge. PDF e-book.

Kalem Bakkal, Asl1. 2019. "From the 'Real' Author to the 'Real' Reader: Manipulation in Translation." transLogos Translation Studies Journal 2 (1): 85-101. doi:10.29228/transLogos.2/1.5.

Karadăg, Ayşe Banu. 2017. "Çeviri, Tarih ve Bellek: Diliçi Edebi Çeviriler Bağlamında Bir İnceleme." [Translation, history, and memory: An analysis within the context of intralingual literary translations.] Paper presented at the 5th International Western Cultural and Literary Studies Symposium, Sivas, October 4-6.

2019. "Türk Edebiyat ve Kültür Dizgesinin Konukseverliğinde Çeviri Roman Deneyimi." [Experience of translated novels with the hospitality of Turkish literary and cultural system.] Doğu Batı 22 (88): 9-25.

Karas, Hilla. 2016. "Intralingual Intertemporal Translation as a Relevant Category in Translation Studies." Target 28 (3): 445-466. doi:10.1075/target.28.3.05kar.

Lotz, Susan. 2017. "It May Be Copyrighted, But It Still Needs Help: Improving Research Questionnaires by Means of Intralingual Translation." Stellenbosch Papers in Linguistics Plus 53:167-181. doi:10.5842/53-0-740.

Mossop, Brian. 2016. “'Intralingual Translation': A Desirable Concept?” Across Languages and Cultures 17 (1): 1-24. doi:10.1556/084.2016.17.1.1.

Öztürk Baydere, Hilal. 2019. "Türk Edebiyatını Diliçi Çevirilerden Okumak: Osmanlıcada ve Günümüz Türkçesinde Refik Halid'in Guguklu Saat'i.” [Reading Turkish literature through intralingual translations: Refik Halid's Guguklu Saat in Ottoman and Modern Turkish.] In Çeviri Üzerine Gözlemler [Observations on translation], edited by Seda Taş, 223-241. Istanbul: Hiperyayın.

Paker, Saliha. 2004. "Türkiye Odaklı Çeviri Tarihi Araştırmaları, Kültürel Hafıza, Unutuş ve Hatırlayış İlişkileri." [Turkey centered translation history research, relations between cultural memory, forgetting, and remembering.] Journal of Turkish Studies 28 (3): 275284.

2014. "Terceme, Te'lîf ve Özgünlük Meselesi." [The issue of terceme, te'lif and originality.] In Metnin Hâlleri: Osmanlı'da Telif, Tercüme ve Şerh [The states of text: original, translation and commentary in the Ottoman tradition], edited by Hatice Aynur, Müjgân Çakır, Hanife Koncu, Selim S. Kuru, and Ali Emre Özyıldırım, 36-71. Istanbul: Klasik.

Vassallo, Clare. 2015. "What's So 'Proper' about Translation? Or Interlingual Translation and Interpretative Semiotics.” Semiotica 2015 (206): 161-179. doi:10.1515/sem-20150022 . 
transLogos 2019 Vol 2 Issue 2

Kalem Bakkal, Asl1, pp. 48-69

Intralingual Translation Has No Name in

A Translation Studies Journal

Turkey: Conceptual Crowdedness in

(c) Diye Global Communications

Intralingual Translation diye.com.tr|diye@diye.com.tr

Zethsen, Karen Korning. 2009. "Intralingual Translation: An Attempt at Description." Meta 54 (4): 795-812. doi:10.7202/038904ar.

Zethsen, Karen Korning, and Aage Hill-Madsen. 2016. "Intralingual Translation and Its Place within Translation Studies: A Theoretical Discussion.” Meta 61 (3): 692-708. doi:10.7202/1039225ar.

Zhang, Huanyao, and Huijuan Ma. 2018. "Intertextuality in Retranslation.” Perspectives 26 (4): 576-592. doi:10.1080/0907676X.2018.1448875. 